\title{
Bilateral perinatal arterial stroke in a neonate
}

\author{
Palaniappan Sashikumar, ${ }^{1}$ Rajesh Gupta, ${ }^{1}$ Brendon Conry ${ }^{2}$
}

${ }^{1}$ Department of Paediatrics and Neonates, Maidstone and Tunbridge Wells Hospital NHS Trust, Pembury, Kent, UK ${ }^{2}$ Department of Radiology, Maidstone and Tunbridge Wells Hospital NHS Trust, Pembury, Kent, UK

\section{Correspondence to} Palaniappan Sashikumar, docsashi@rediffmail.com

Accepted 5 March 2014

\section{DESCRIPTION}

Perinatal arterial ischaemic stroke (PAIS) is the cause for $10-15 \%$ of neonatal seizures and approximately $30 \%$ of childhood hemiplegia. ${ }^{1} \mathrm{We}$ report a case of bilateral arterial stroke which initially was thought to be hemimegalencephaly and unilateral arterial stroke.

A term baby was noticed to have paucity of movements of his right upper limb in the immediate postnatal period. A brain MRI on day 7 showed large porencephalic cyst involving the entire territory of the left middle cerebral artery (MCA). There was also a shift of the midline to the left due to a mass effect from the right hemisphere (figure 1A, B). Provisional diagnosis of antenatal left-sided PAIS and rightsided hemimegalencephaly was made following opinion from tertiary paediatric neurologist. Parents denied further investigations at this stage.

Baby developed infantile spasms at 3 months of age. MRI at 7 months showed new porencephaly on the right side in addition to the previous left side porencephaly (figure 1C, D). This clarified that the initial presumed right hemimegalencephaly was an MCA and anterior cerebral artery territory infarction in evolution with a contralateral left infarct already well-established at birth.
To cite: Sashikumar $P$ Gupta R, Conry B. BMJ Case Rep Published online: [please include Day Month Year] doi:10.1136/bcr-2013202059

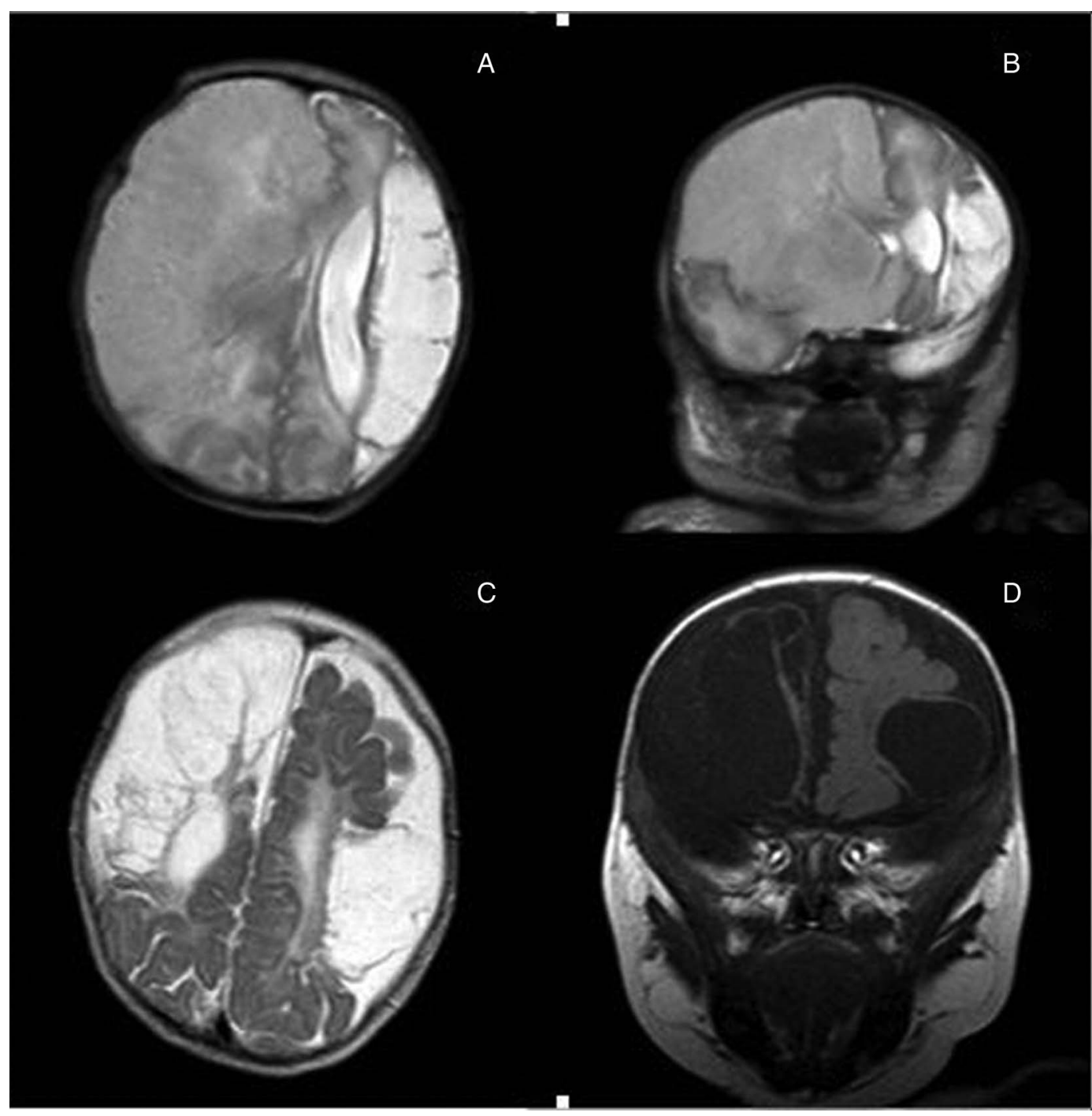

Figure 1 (A) and (B) are axial and coronal T2-weighted (T2-W) MR images showing a large area of tissue loss corresponding to the territory of the left middle cerebral artery (MCA) and a large right hemisphere, with shift of the midline to the left. There is a loss of tissue detail but abnormality is seen in the territory of the MCA including the central grey matter and the anterior cerebral artery (ACA). (C) and (D) equivalent images (axial T2-W and coronal T1-weighted) taken at 7 months clearly show tissue loss in both hemispheres consistent with bilateral MCA and unilateral ACA stroke. 
Unfortunately no diffusion-weighted images (DWI) were obtained on the initial imaging as the baby did not settle long enough with feed and wrap scans. Almost certainly these would have made a clear diagnosis of infarction. This case highlights

\section{Learning points}

- Diffusion-weighted images should be part of MRI assessments of neonates with suspected infarctions.

- MRI under sedation or anaesthetic should be considered when initial MRI without sedation does not provide adequate information.

- Reconsider alternative diagnosis in unusual presentations. the need for routine DWI in neonatal MR assessment with consideration of sedation or at least early repeat scan where diagnosis is uncertain in the context of clinical symptoms. ${ }^{2}$

Contributors PS contributed by writing the case report and literature review, RG was involved in writing the case reportand coordination. $\mathrm{BC}$ contributed by giving radiological expert opinion on MRI report and writing the case report.

Competing interests None.

Patient consent Obtained.

Provenance and peer review Not commissioned; externally peer reviewed.

\section{REFERENCES}

1 Rutherford MA, Ramenghi LA, Cowan FM, et al. Neonatal stroke. Arch Dis Child Fetal Neonatal Ed 2012;97:F377-84.

2 Cerebral infarction in the full-term infant. In: Rutherford MA, ed. MRI of the Neonatal Brain. London: WB Saunders, 2001. http://www.mrineonatalbrain.com/ ch04-07.php (accessed 1 Jun 2013).

Copyright 2014 BMJ Publishing Group. All rights reserved. For permission to reuse any of this content visit http://group.bmj.com/group/rights-licensing/permissions.

BMJ Case Report Fellows may re-use this article for personal use and teaching without any further permission.

Become a Fellow of BMJ Case Reports today and you can:

- Submit as many cases as you like

- Enjoy fast sympathetic peer review and rapid publication of accepted articles

- Access all the published articles

- Re-use any of the published material for personal use and teaching without further permission

For information on Institutional Fellowships contact consortiasales@bmjgroup.com

Visit casereports.bmj.com for more articles like this and to become a Fellow 